\title{
Violência contra a mulher, machismo e patriarcado no enquadramento jornalístico
}

\author{
Rafael Bellan Rodrigues de Souza ${ }^{1}$ \\ Yara Lopes ${ }^{2}$
}

\section{Resumo}

O artigo apresenta discussão teórica sobre machismo na sociedade patriarcal, a violência contra a mulher e o papel do jornalismo enquanto noticiador de matérias com casos desse tipo de agressão. A proposta é questionar se a hegemonia e a ideologia dominante estão presentes nos conteúdos veiculados pela mídia. A ferramenta metodológica pensada para fazer essas análises é o enquadramento noticioso, com inspiração em Entman (1993) e Porto (2002). Autoras que investigam a temática de gênero, como Saffioti (2015) e Fraser et al (2019) são utilizadas nessa discussão, enquanto o debate sobre o jornalismo e a hegemonia ficam por conta de autores como Moretzsohn (2007) e Moraes (2010).

Palavras-chave: Jornalismo. Violência contra mulher. Enquadramento.

\section{Violence against woman, sexism and patriarchy in the News framing}

\section{Abstract}

The article presents a theoretical discussion about sexism in the patriarchal society, the violence against woman and the journalism's role such as news maker of this kind of aggression. The proposal is to question if the mainstream hegemony and ideology are presents in the media contents. The methodological tool that can make theses analysis is the news framing, using the authors Entman (1993) and Porto (2002). Gender writers as Saffioti (2015) and Fraser et al (2019) are used in this

1 Professor adjunto do Departamento de Comunicação e do Programa de PósGraduação em Comunicação e Territorialidades da Universidade Federal do Espírito Santo (Ufes). Possui pós- doutorado no Departamento de Comunicação e Artes da Universidade de São Paulo (ECA-USP), doutorado em Ciências Sociais pela Universidade Estadual Paulista Júlio de Mesquita Filho (Unesp). E-mail: rafaelbellan@yahoo.com.br.

2 Mestranda do Programa de Pós-graduação em Comunicação e Territorialidades da Universidade Federal do Espírito Santo. Graduada em Comunicação Social com habilitação em Jornalismo pela Universidade Federal do Rio de Janeiro. E-mail: yarak.lopes@gmail.com.

Revista Pauta Geral-Estudos em Jornalismo, Ponta Grossa, vol. 6, n. 2, p. 19-34, Jul/Dez, 2019. 


\section{REVISTA PAUTA GERAL}

\section{ESTUDOS EM JORNALISMO}

10.5212/RevistaPautaGeral.v.6.i2.0002

discussion while journalism and hegemony are approached by Moretzsohn (2007) and Moraes (2010).

Keywords: Journalism. Violence against woman. Framing.

\section{Introdução}

A opressão de gênero é definida por Fraser et al (2019) como originária da opressão de classe. Assim, para falar de machismo e misoginia é necessário entender que esta é uma realidade inserida em um sistema capitalista. Neste contexto, gênero, raça, classe e orientação sexual ditam privilégios na sociedade, que é patriarcal. Saffioti (2015) ressalta que, inseridos na sociedade de classes, tanto homens quanto mulheres não se apropriam totalmente do valor do que produzem, mas estas ficam com uma parcela menor do que estes. Moraes (2010) aponta que, na concepção gramsciana, a manutenção da hegemonia, que se dá não apenas nos âmbitos econômicos, mas políticos, culturais e sociais, é possível por meio do exercício de poder de uma classe dominante que consegue angariar apoio ao seu estilo de pensar. Ele destaca a existência de instituições que constituem a sociedade civil e que podem contribuir para a difusão de pensamentos hegemônicos, dentre elas os meios de comunicação. Mas se pensarmos no jornalismo moderno que, segundo Moretzsohn (2007), tenta se colocar como objetivo, imparcial, transparente e até mesmo a favor das questões sociais, a conclusão poderia ser a de que não haveria uma tendência para nenhum lado ou até que misoginia e machismo seriam combatidos, visto que diminuir essa opressão já é evidenciado como uma luta social em nível mundial. Para trilhar um caminho sobre uma possível contribuição da mídia para manutenção ou diminuição de preconceito de gênero e ódio às mulheres, torna-se indispensável um debate teórico sobre as bases dessa problemática, além de uma análise empírica de publicações. O enquadramento noticioso é uma ferramenta que pode auxiliar esse tipo de pesquisa, utilizando autores como Entman (1993) e Porto (2002) na investigação da produção de sentidos e representações jornalísticas. Para Entman (1993), o enquadramento é uma ferramenta de análise que utiliza saliência e seleção para construir argumentos em relação a algum assunto. Ao buscar em portais de periódicos sobre jornalismo e violência contra a mulher, percebe-se que não são muitas as pesquisas voltadas para o tema. Pesquisas utilizando o enquadramento e a violência também não são tão numerosas. Mas já existem trabalhos 


\title{
REVISTA PAUTA GERAL
}

\section{ESTUDOS EM JORNALISMO}

10.5212/RevistaPautaGeral.v.6.i2.0002

desenvolvidos nesta área que apresentam resultados importantes. Assim, o objetivo desse artigo é considerar a possibilidade de utilização do enquadramento para analisar matérias jornalísticas que tratem da violência contra a mulher e assim começar a construir análises mais palpáveis sobre como a mídia trata questões de gênero.

\section{Gênero, patriarcado e violência}

Autoras como Saffioti (2015), Federici (2019) e Beauvoir (2016) são conhecidas por tratar do tema de gênero, história da mulher, machismo e misoginia. Elas traçam os alicerces e os fundamentos concretos de uma sociedade patriarcal.

\begin{abstract}
A hierarquia dos sexos manifesta-se a ela primeiramente na experiência familiar; compreende pouco a pouco que, se autoridade do pai não é a que se faz sentir mais quotidianamente, é, entretanto, a mais soberana [...] Tudo contribui para confirmar essa hierarquia aos olhos da menina. Sua cultura histórica, literária, as canções, as lendas com que a embalam são uma exaltação do homem. (BEAUVOIR, 2016, p. 28)
\end{abstract}

Saffioti (2015) discute os fenômenos sociais que incidem sobre a violência contra a mulher e tece em sua abordagem análises relativas a gênero, trabalho, capitalismo e poder. Em relação ao conceito de patriarcado pontua:

À medida que as (os) teóricas (os) feministas forem se desvencilhando das categorias patriarcais, não apenas adquirirão poder para nomear de patriarcado o regime atual de relações homem-mulher, como também abandonarão a acepção de poder paterno do direito patriarcal e o entenderão como direito sexual. Isto equivale a dizer que o agente social marido se constitui antes que a figura do pai. (SAFFIOTI, 2015, p. 59)

Nessa posição inferiorizada característica da sociedade patriarcal, a mulher sofre ainda diversas formas de violência. Ela aponta que a violência é uma ruptura da integridade, seja ela física, psíquica, sexual ou moral. Em qualquer tipo de agressão, as modalidades emocional e moral aparecem. Destaca também que a dificuldade é conseguir, nos casos de violência doméstica, diferenciar o que a ruptura da integridade e o que é uma obrigação histórica devido ao gênero.

Desta maneira, cada mulher colocará o limite em que um ponto distinto do continuum entre agressão e direito dos homens sobre as mulheres. Mais do que isto, a mera existência desta tenuidade representa a violência. Com efeito, paira sobre a cabeça de todas as mulheres a 


\title{
REVISTA PAUTA GERAL
}

\section{ESTUDOS EM JORNALISMO}

10.5212/RevistaPautaGeral.v.6.i2.0002

ameaça de agressões masculinas, funcionando isto como mecanismo de sujeição aos homens, inscrito nas relações de gênero. (SAFFIOTI, 2015, p. 80)

Tratando-se de violência, a autora discorre sobre como é levado em consideração a manutenção dos direitos humanos, sendo que estes foram pensados pautados nos homens, não nas mulheres. No Brasil, há alguns anos foi criada legislação específica para os casos de violência contra a mulher: a Lei Maria da Penha, que cria mecanismos para coibir a violência doméstica (física, sexual, verbal, psicológica e patrimonial) e está em vigor desde 2006; a Lei do Feminicídio, o assassinato de mulheres marcado pela questão de gênero, neste caso em vigor desde 2015; e mais recentemente a Lei da Importunação Sexual, em vigor desde 2018. Apesar da existência desse aparato legal, a violência continua. Federici (2019) critica a reforma jurídica como principal meio de intervenção do governo nos casos de violência contra a mulher.

\begin{abstract}
Inclusive, a campanha pelo fim da violência contra as mulheres ganhou impulso nos últimos anos centrando-se no estupro e na violência doméstica - de acordo com as recomendações das Nações Unidas -, enquanto a violência inerente ao processo de acumulação capitalista foi ignorada, bem como a violência da fome, das guerras e das estratégias de contrainsurgência que, entre os anos 1980 e 1990, abriram caminho para a globalização econômica. (FEDERICI, 2019, p. 139)
\end{abstract}

Apesar das campanhas, os números são altos. A Agência Patrícia Galvão mantém números atualizados da violência contra a mulher. Em seu cronômetro de dados ${ }^{3}$, aponta que uma mulher é vítima de estupro a cada 9 minutos; três mulheres são vítimas de feminicídio a cada um dia; uma pessoa trans ou gênero-diversas é assassinada a cada dois dias; e uma mulher registra agressão sob Lei Maria da Penha a cada dois minutos. A plataforma traz ainda a informação de uma pesquisa realizada pelo próprio Instituto Patrícia Galvão em $2013^{4}$, na qual quase metade dos homens entrevistados concordam que "mulher que apanha é porque provoca", sendo que uma parte das mulheres também concordou com a afirmação.

3 Disponível em: https://dossies.agenciapatriciagalvao.org.br/violencia-em-dados/. Acesso: 18 ago. 2019.

4Disponível em https://dossies.agenciapatriciagalvao.org.br/violencia-emdados/brasileiros-ainda-acham-que-as-mulheres-vitimas-de-violencia-provocamagressao/. Acesso: Acesso: 18 ago. 2019.

Revista Pauta Geral-Estudos em Jornalismo, Ponta Grossa, vol. 6, n. 2, p. 19-34, Jul/Dez, 2019. 


\section{REVISTA PAUTA GERAL}

\section{ESTUDOS EM JORNALISMO}

10.5212/RevistaPautaGeral.v.6.i2.0002

Fraser et al (2019) trata da violência como uma particularidade da sociedade capitalista, argumentando que este sistema se sustenta em uma mistura de consentimento e coerção. Ressaltam que a violência de gênero que está presente com tanta frequência na sociedade atual é resultado tanto dos efeitos do capitalismo quanto das dinâmicas familiares. Para elas, a agressão está institucionalizada e instrumentalizada como uma forma de controle e poder, em uma hierarquia de gênero, raça e classe. As leis criadas com a justificativa de proteger a mulher também não são vistas como boas alternativas.

A resposta carcerária ignora a importância de alternativas para as sobreviventes. Leis criminalizando o estupro marital ou a agressão no ambiente de trabalho não vão ajudar as mulheres que não têm outro lugar pra ir nem aquelas sem nenhum meio para chegar lá. (FRASER et al, 2019, p. 61)

Apesar da compreensão de que as violências descritas na legislação podem não corresponder a toda complexidade de agressões, inclusive simbólicas, elas são a maneira mais palpável de, ao menos inicialmente, abordar o assunto. Tratando-se de jornalismo, a existência dessas leis começou a pautar o noticiário, além de também ser uma forma da comunicação tocar neste assunto. Mas não basta apenas tematizar e fazer a violência contra a mulher ser pauta, a maneira como essa abordagem é feita também deve ser analisada. Ainda em um contexto de comunicação de massa e hegemônica, observar o enquadramento jornalístico dessas matérias pode auxiliar a compreensão do que ainda se pensa sobre as mulheres e a violência sofrida por elas.

\section{Jornalismo, hegemonia e ideologia}

Moraes (2010) tece considerações sobre a hegemonia na perspectiva do filósofo marxista Antonio Gramsci. Ele explica que a hegemonia acontece quando um grupo ou classe social consegue colocar seus pensamentos culturais e políticos como dominantes sobre os demais grupos e classes. A hegemonia não estaria ligada apenas a questões econômicas, mas envolveria também cultura, ética, percepções e representações. Assim, esta não se dá por coerção e força simplesmente, pois se trata na verdade de um consentimento coletivo de determinadas regras morais e crenças. O processo para conseguir conquistar essa hegemonia é longo e pode ser feito justamente por um grupo que tenha liderança histórica e que articule diversos grupos sociais.

Revista Pauta Geral-Estudos em Jornalismo, Ponta Grossa, vol. 6, n. 2, p. 19-34, Jul/Dez, 2019. 


\title{
REVISTA PAUTA GERAL
}

\section{ESTUDOS EM JORNALISMO}

10.5212/RevistaPautaGeral.v.6.i2.0002

\begin{abstract}
uma classe é hegemônica, dirigente e dominante até o momento em que - através de sua ação política, ideológica, cultural - consegue manter articulado um grupo de forças heterogêneas, consegue impedir que o contraste existente entre tais forças exploda, provocando assim uma crise na ideologia dominante, que leve à recusa de tal ideologia, fato que irá coincidir com a crise política das forças no poder. (GRUPPI, 1978, p. 67)
\end{abstract}

Inseridos em uma sociedade capitalista e patriarcal, é possível que os nossos meios de comunicação veiculem textos permeados por pensamentos hegemônicas que corroborem esse modelo. O que não significa que o público absorva integralmente e verticalmente o que consome. Hall (1980) explica que o processo comunicacional em circuito de emissor/mensagem/receptor tem sido bastante criticado justamente por deixar o foco na troca de mensagens e não demonstrar a complexa estrutura que é envolvida, que articula produção, circulação, distribuição/consumo, reprodução. O autor cria um esquema em diagrama do discurso significativo, apresentando códigos de codificação e decodificação, que para ele podem não ser perfeitamente simétricos.

A falta de adequação entre os códigos tem a ver em grande parte com as diferenças estruturais de relação e posição entre transmissores e audiências, mas também tem algo a ver com a assimetria entre os códigos da "fonte" e do "receptor" no momento da transformação para dentro e para fora da forma discursiva. O que são chamadas de "distorções" ou "mal-entendidos" surgem precisamente da falta de equivalência entre os dois lados na troca comunicativa. Mais uma vez, isso define a "autonomia relativa", mas também a "determinação" da entrada e saída da mensagem em seus momentos discursivos. (HALL, 1980, p. 391)

Apesar de não haver um sistema de agulha hipodérmica, no qual tudo que é dito na mídia seja automaticamente absorvido pelo público, existe algum nível de influência. Segundo Moraes (2010), os meios de comunicação têm como objetivo promover uma regulação da opinião pública através da difusão de informações com um agendamento próprio, inclusão e exclusão de temas e esvaziamento de análises mais críticas, evitando o conflito. Ouve-se comumente que nunca houve tanta quantidade de informação e de entretenimento disponível para a população como há atualmente, mas não se pode esquecer de que a produção massiva desse conteúdo ainda está nas mãos de um grupo pequeno.

Revista Pauta Geral-Estudos em Jornalismo, Ponta Grossa, vol. 6, n. 2, p. 19-34, Jul/Dez, 2019. 


\title{
REVISTA PAUTA GERAL
}

\section{ESTUDOS EM JORNALISMO}

\author{
10.5212/RevistaPautaGeral.v.6.i2.0002
}

\begin{abstract}
A mídia precisa ter seus radares permanentemente ativados para captar sinalizações, insatisfações e carências - e com isso preencher vácuos abertos, antecipar tendências, criar modismos, atenuar variações e repensar aproximações. Sem nunca perder de vista que os deslocamentos devem ocorrer, o máximo possível, dentro das margens de controle delineadas por estrategistas e gestores coorporativos, que tomam preferências e gostos de segmentos do público como elementos essenciais à escolha de planos mercadológicos que alarguem a base de audiência e o volume de usuários, assinantes, patrocínios e publicidade. (MORAES, 2010, p. 71)
\end{abstract}

Importante ressaltar que é o conjunto de notícias, de jornais, de veículos, que seguindo uma lógica hegemônica pode contribuir para uma atenção a determinados assuntos em detrimento de outros e a uma normalização e conformidade com a realidade. Assim, para ter uma visão mais abrangente de como os veículos de comunicação tratam da questão de gênero, não basta ver uma matéria, mas o conjunto delas ao longo de um determinado período, observando se existe um padrão de enquadramento e critérios de noticiabilidade que se relacionem ou tensionem a direção moral e intelectual reinante.

\section{Jornalismo, machismo e misoginia}

$\mathrm{Na}$ sociedade machista, misógina e patriarcal, às mulheres foram negados o estudo, o trabalho remunerado e as escolhas particulares, deixando-as por muito tempo confinadas no espaço privado, responsáveis por todas as tarefas domésticas e sem participação política. Depois de muita luta de mulheres por uma libertação patriarcal, alguns pontos mudaram e diretos foram lentamente adquiridos. Mas a sociedade ainda é machista e a cultura é de violência contra a mulher, visto que apesar das mudanças, ainda estamos em uma realidade capitalista cuja lógica transforma quase tudo em mercadoria, até mesmo as mulheres. Abrir espaço para algumas mudanças faz parte inclusive dessa racionalidade capitalista, que tenta se apropriar até mesmo das lutas, cedendo em alguns pontos, para manter sua hegemonia.

Fraser et al (2019) trazem uma perspectiva da luta das mulheres com um olhar de luta também contra o capitalismo. Apontam que o feminismo para os $99 \%$ é internacionalista, anticapitalista e antirracista, tem compromisso com o bem viver, com a liberdade do outro e com a natureza, e que luta contra o feminismo do $1 \%$ que detém riqueza e não serve a toda a humanidade. O que é proposto é uma luta para conseguir retirar o capitalismo e implementar um modelo que tenha igualdade de gênero, raça e 


\section{REVISTA PAUTA GERAL}

\section{ESTUDOS EM JORNALISMO}

10.5212/RevistaPautaGeral.v.6.i2.0002

classe, considerando que a hierarquia de poder que funde essas três categorias é o que permite a violência contra a mulher.

A violência, em todas as formas, é parte integrante do funcionamento cotidiano da sociedade capitalista - pois é apenas por meio de uma mistura de coerção brutal e consentimento construído que o sistema consegue se sustentar com perfeição. (FRASER et al, 2019, p. 65)

Moretzshon (2007) pontua que o jornalismo moderno gosta de se descrever como objetivo, imparcial, neutro e com dever de noticiar o que interessa a sociedade. Levando essa descrição em consideração, seria possível concluir que a problemática da mulher deveria ter destaque, visto que elas são maioria da população e que o machismo e patriarcado não prejudicam apenas um gênero, mas é nocivo a todos. Todavia, tudo que já foi dito ao longo deste texto mostra que essa objetividade não existe da maneira que se prega. Para Ciro Marcondes Filho (1989) existe uma "política da notícia" que costuma incentivar apatia e passividade, aceitação e submissão das pessoas. Ele aponta ainda que, para sobreviver, o jornal traz tanto as notícias que atemorizam a população, como roubos e greves, quanto que trazem uma tranquilidade e bem-estar, como casamentos de celebridades e vitórias de times esportivos.

Quanto às questões sociais que são trazidas, muitas vezes existe uma sensação de vingança ou penalização, mas não de real descontentamento quanto ao gerador desse problema social. O exemplo que o autor traz reflete sobre como a notícia da morte de uma criança pode desencadear um sentimento de condenação deste ato, mas que notícias com dados sobre as dezenas de milhares de crianças que morrem no Nordeste por desnutrição não causa a mesma sensação de revolta. É possível trazer essa reflexão também para a questão da mulher. Quando uma mulher é brutalmente assassinada por um companheiro e a notícia sai em diversos veículos, suscita-se o debate sobre a violência contra a mulher e o público costuma mostrar-se indignadas. Normalmente, os feminicídios que ganham uma grande repercussão em meios de comunicação de massa são os de mulheres brancas e de classe social alta, mesmo que as mulheres negras e periféricas sejam as maiores vítimas de violência no Brasil, mas elas não geram tanta empatia com o público. Essa observação vai de acordo com o que Marcondes Filho (1989) expressa sobre o anormal que tenha interesse da hegemonia ganhar espaço na mídia, não simplesmente o anormal isolado. Além disso, as reportagens que retratam 2019. 


\section{REVISTA PAUTA GERAL}

\section{ESTUDOS EM JORNALISMO}

10.5212/RevistaPautaGeral.v.6.i2.0002

feminicídio dificilmente mostram que essa é uma consequência de um ciclo de violência e que essa violência tem origem no machismo, na misoginia, no patriarcado e que tudo isso está também ligado ao capitalismo e à propriedade privada. Engels (1984) explica como a necessidade de deixar a herança para o seu filho contribuiu para a mudança de uma sociedade matriarcal para patriarcal e como a própria ideia de propriedade privada passou aos homens o direito a bens que os deram mais poder sobre as mulheres. Para entender como chegamos ao ponto onde estamos hoje é preciso recorrer à história e questionar se realmente tudo sempre foi assim e porque é assim atualmente. Essa compreensão é essencial para a transformação. Voltando ao exemplo de violência contra a mulher na mídia, do mesmo modo que os dados sobre mortes das crianças gera pouca comoção comparados a uma notícia de uma criança morta, as matérias que saem com os dados de violência contra a mulher também não geram tanta emoção quanto a de um caso. Para Marcondes Filho (1989), isso se explica pelo fato da produção das notícias trazer algo que é de certa forma estranho à população, pois não é possível politizar sem um envolvimento com a sua realidade.

A tranquilização, o não-envolvimento do receptor com as questões que
direta ou indiretamente vão interferir efetivamente na sua vida (economia,
política, etc.), estão indissoluvelmente ligadas ao processo de trabalho no
capitalismo. [...] A necessidade de harmonia, portanto, surge da
desintegração do ser humano no processo de trabalho, de seu
isolamento com a concorrência, da dispersão do tempo de vida em puros
valores de trabalho e lazer. (MARCONDES FILHO, 1989, p. 19)

O jornalismo traz matérias sobre violência contra a mulher, mas normalmente essas notícias estão dentro da editoria policial e trazem muito pouca reflexão e criticidade, apresentando naquele estilo tradicional do jornalismo moderno informações principais no lead e muitas vezes alguma fala do acusado da agressão, que costuma se defender alegando provocação da mulher ou ciúmes. Os crimes chegam a ser descritos como passionais. Dificilmente há espaço para a fala dessa mulher ou de algum representante que possa discutir sobre a situação da violência. A repetição desse padrão pode causar uma espécie de reforço na opinião de que a violência contra a mulher é causada até mesmo como uma resposta às suas próprias atitudes. Não há uma repetição, assim como há de que a mulher sofreu violência com uma justificativa do agressor, de que a violência não é aceitável e que resultado do machismo e do patriarcado.

Revista Pauta Geral-Estudos em Jornalismo, Ponta Grossa, vol. 6, n. 2, p. 19-34, Jul/Dez, 2019. 


\section{REVISTA PAUTA GERAL}

\section{ESTUDOS EM JORNALISMO}

10.5212/RevistaPautaGeral.v.6.i2.0002

\section{Jornalismo, enquadramento e violência}

O uso de enquadramento nas pesquisas sobre comunicação e jornalismo são relativamente recentes. Segundo Porto (2002), os estudos começaram com o livro Frame Analysis, escrito pelo sociólogo Erving Goffman em 1974. A obra de Goffman é a primeira a fazer articulações teóricas mais sistematizadas, utilizando o conceito para fazer análises das interações sociais. No caso do campo da comunicação, Porto afirma que os estudos de enquadramento se tornaram mais relevantes com a publicação do livro Making News, da socióloga Gaye Tuchman, em 1978, baseado na obra de Goffman.

Outra grande referência nos estudos de enquadramento relacionados ao jornalismo é Robert Entman. Ele também tem uma citação que se tornou muito famosa nas pesquisas relacionadas a essa ferramenta de análise de conteúdo:

Enquadramento essencialmente envolve seleção e saliência. Enquadrar é selecionar alguns aspectos de uma realidade percebida e fazê-los mais salientes em um texto comunicativo, de maneira a promover um problema de definição particular, uma interpretação causal, uma avaliação moral, e/ou tratamento recomendado para o item descrito. (ENTMAN, 1993, p. 52 ; itálicos no original; tradução nossa)

Alguns trabalhos podem ser destacados por seus resultados ao tratar do tema. Santos (2018) analisou matérias do Jornal Zero Hora sobre homicídios de mulheres veiculadas ao longo de 2016, com objetivo de analisar as representações sociais produzidas pela mídia sobre este fenômeno. A pesquisa analisou 48 matérias, sendo que todas elas estavam localizadas no caderno policial e seis apareceram em chamadas na capa. A autora buscou compreender a leitura que a mídia tinha desses homicídios, observando pontos como quais casos são mais destacados, a inclusão dos antecedentes criminais das mulheres e até mesmo a identificação do homicídio como um crime passional. Para fazer essa análise, utilizou referencial teórico sobre representações sociais da violência a partir da socióloga Maria Stela Grossi Porto e debateu qual lugar da mídia na construção e difusão das percepções de violência, mais especificamente a violência contra a mulher. Com os dados das 48 matérias, definiu as seguintes categorias: vítima, culpabilização da vítima, autor, circunstâncias, investigação, passional, violência por parceiro íntimo, violência doméstica e intrafamiliar, violência extrafamiliar, violência no contexto da criminalidade urbana, fonte oficial, fonte não oficial, tamanho das notícias e 2019. 
chamada de capa. Dentre as conclusões feitas no trabalho, a pesquisadora destaca o fato de muitos homicídios serem tratados como decorrentes de criminalidade, mas terem o fator gênero como ponto crucial; a faixa etária de 20 das 32 mulheres assassinadas ser entre 15 e 24 anos, fato que não é destacado pela mídia; uma regularidade na presença de matérias de homicídios de mulheres, mas a atenção na produção depende do grau de crueldade do crime e da falta de elementos que provem uma postura considerada moral da mulher vítima; a grande presença de falas de policiais e delegados nas matérias, apontando que feminicídios e homicídios de mulheres são tratados dentro da esfera de segurança e de política públicas, apesar de não ter havido realmente uma proteção dessas mulheres pelo governo. Assim, conclui que não há ainda um tratamento pela mídia da violência como um processo completo e multifacetado, considerando por exemplo raça e classe, mas limitando-se ao enquadramento policial.

Saad (2018) discutiu o "feminicídio íntimo", causa principal das mortes violentas de mulheres, resultado de um ciclo de violências, mas que segundo a autora ainda é invisibilizado pelas instituições e também pela mídia. A pesquisadora analisou matérias do jornal goiano Daqui sobre assassinatos ou tentativas de assassinatos de mulheres cujos acusados ou suspeitos eram companheiros ou ex companheiros íntimos das vítimas. $O$ objetivo era caracterizar o perfil das vítimas e dos agressores, fazendo uma análise do discurso social da produção das matérias jornalísticas. Foram encontradas 121 matérias sobre feminicídio íntimo e tentativa de feminicídio entre março de 2015, quando a Lei do feminicídio entrou em vigor, e junho de 2016. Foram utilizadas além da análise de discurso crítica, teorias feministas e da comunicação para entender como os fatos foram tratados pelo veículo de comunicação. A autora encontrou traços comuns nas matérias do veículo, como a caracterização de mulheres segundo padrões patriarcais da sociedade as mulheres "honradas" e as "perdidas"- e silenciamento dessas vítimas nos textos. Embora os títulos das matérias trouxessem uma ideia de sofrimento dessas mulheres, 0 conteúdo focava sempre no autor, mostrando inclusive suas explicações para cometer o crime. O homem também é descrito segundo critérios patriarcais machistas, com virilidade e masculinidade. Além disso, o uso do termo "feminicídio" foi apenas no sentido de falar sobre um agravante da pena, sem discutir as raízes dessa violência de gênero. A conclusão foi a de que o jornal caracteriza o feminicídio íntimo como crime passional, legitimando ou naturalizando o crime através do discurso, sem focar em questões de gênero, e fortalecendo os estereótipos dos envolvidos.

Revista Pauta Geral-Estudos em Jornalismo, Ponta Grossa, vol. 6, n. 2, p. 19-34, Jul/Dez, 2019. 


\section{REVISTA PAUTA GERAL}

\section{ESTUDOS EM JORNALISMO}

10.5212/RevistaPautaGeral.v.6.i2.0002

Góes (2014) busca analisar o sensacionalismo jornalístico que retrata a violência, buscando ir além das rotulações superficiais, utilizando, assim, enquadramento, relação dos frames com representações sociais de pobreza e violência, e a avaliação desse sensacionalismo pela ótica ética do jornalismo. Foi analisado o jornal Cinform entre 2008 e 2012, e através de análise de conteúdo e entrevistas com repórteres e o diretor de jornalismo, entendeu-se o sensacionalismo como um enquadramento, uma articulação entre os trabalhadores para transformar determinados assuntos violentos em relatos de barbárie. Dentre as matérias analisadas nesta pesquisa, estão também matérias de violência contra a mulher, apesar de não ser o objetivo do trabalho falar especificamente de gênero. Ainda assim, foi utilizada a metodologia de enquadramento para analisar como o veículo apresenta também esse tipo de situação. Foram analisados 39 conjuntos sensacionalistas - manchete principal, chamada na capa, reportagem e apresentação visual. $\mathrm{Na}$ conclusão do trabalho, o autor ressalta por exemplo a maneira como as matérias descrevem casos de violência contra a mulher, enfatizando, por exemplo, as características sociais de autores e vítimas de poder aquisitivo maior com tom de surpresa, enquanto acusados de classes sociais mais baixas são descritos como monstros. Há também muita sexualização das situações criminosas, principalmente envolvendo estupro, e uso de moralidade no texto. $O$ autor percebeu que 0 enquadramento sensacionalista valoriza a dramaticidade dos acontecimentos, com histórias de impacto e viés moral.

Lage et al (2018) analisa a cobertura jornalística sobre o parto e a maneira como as mulheres que são mães são tratadas, fazendo um enquadramento sobre a moral que regula os corpos dessas mulheres, o respeito às suas decisões e as experiências de violência obstétrica. Foi analisada a cobertura que o jornal Folha de São Paulo fez sobre o parto a partir da discussão sobre a Resolução Normativa 368/15 da ANS. O corpus é composto de 38 matérias do jornal e parte-se da ideia de que a mídia atua ativamente na produção de avaliações sobre as pessoas e seus estilos de vida. A abordagem da questão da maternidade e do parto é permeada no trabalho pelo conceito de vulnerabilidade como local problemático para pensar a condição da mulher mãe na mídia. Concluiu-se que o jornalismo utilizou enquadramentos variados para tratar dessa questão, o que aponta para a existência de tensões sobre o entendimento de vulnerabilidade e capacidade de agir das mulheres. 


\section{REVISTA PAUTA GERAL}

\section{ESTUDOS EM JORNALISMO}

10.5212/RevistaPautaGeral.v.6.i2.0002

Bianchi e Persegona (2018) levantam uma discussão teórica sobre o lugar do jornalismo em abordagens de gênero e coberturas de violência contra a mulher. Foram coletadas 22 matérias do portal A Rede e 9 matérias do portal RSN dos meses outubro e novembro de 2017. A pesquisa entende o jornalismo como uma ferramenta central na midiatização de debates e com capacidade de definir visões de mundo. Percebeu-se na análise a falta de contextualização sobre o tema e também uma baixa produção jornalística.

Outras pesquisas trazem também contribuições para esse debate, como a de Marques e Biondi (2018), que analisa fotografias de mulheres beneficiárias do programa Bolsa Família entendendo que as vulnerabilidades e o empobrecimento que costumam ser associadas ao gênero; a de Quirino e Moura (2018), que estuda o enquadramento jornalístico do genocídio dos jovens negros, ressaltando a importância de fazer uma contextualização de interseccionalidade de gênero, raça e classe nesses casos; a de Belin (2019) que analisa a cobertura jornalística do assassinato de uma mulher em situação de rua, observando que a questão de gênero e situação de maternidade apareceram de maneira muito tímida.

\section{Conclusão}

Com a promulgação de leis de proteção à mulher, a violência de gênero virou pauta jornalística, com uma divulgação mais expressiva de casos de agressão, estupro e feminicídio. Para além da necessidade de discutir a violência como mais do que os pontos discutidos nas leis e de entender que um aparato legal não é suficiente para a transformação do status quo, é importante também refletir sobre como o que já se tem até agora em relação ao assunto é tratado pela mídia, especificamente veículos jornalísticos. A produção de notícia tem se tornado cada vez mais acelerada com a lógica capitalista que comprime a noção de tempo e de espaço e nos veículos é mais comum encontrar matérias mais curtas e diretas, ditas pelo jornalismo como objetivas. Mas até mesmo o tamanho dessas notícias pode ser um critério a ser avaliado teoricamente para conseguir entender qual é o discurso jornalístico em relação às questões de gênero, como foi destacado por Góes (2014) e Saad (2018), que enxergaram superficialidade e poucos desdobramentos nas matérias, além de até mesmo uma baixa produção, como observado por Bianchi e Persegona (2018). 


\section{REVISTA PAUTA GERAL}

\section{ESTUDOS EM JORNALISMO}

10.5212/RevistaPautaGeral.v.6.i2.0002

O espaço dado pelos veículos, as entrevistas dispostas na matéria, que podem ou não conter uma fala favorável à vítima, a construção da narrativa do crime, que dependendo da maneira feita culpabiliza a mulher pela agressão que sofre, ou até mesmo a normalização e institucionalização da violência são pontos que podem ser observados em um conjunto de matérias de um ou mais veículos. Jornais de diferentes localidades brasileiras ainda utilizam de moralidade, características estereotipadas como vulnerabilidade e empobrecimento para se referir à mulher, e apelo ao emocional para tratar de casos que envolvem violência. Entende-se, assim, que existem alguns padrões que podem ser identificados, através da ferramenta metodológica do enquadramento, nas coberturas jornalísticas de violência contra a mulher e que esses pontos em comum têm a possibilidade de promover um entendimento em relação a como as questões de gênero ainda são vistas, entendidas e retratadas na atualidade.

\section{Referências}

ARRUZZA, Cinzia; BHATTACHARYA, Tithi; FRASER, Nancy. Feminismo para os $99 \%$ um manifesto. São Paulo: Editora Boitempo, 2019.

BEAUVOIR, Simone de. O segundo sexo, volume 1. Rio de Janeiro: Nova Fronteira, 2016.

BELIN, Luciane Leopoldo. Das ruas para a mídia: o assassinato de uma mulher em situação de rua no Rio de Janeiro e seu enquadramento midiático. Estudos em Jornalismo e Mídia, Florianópolis, v. 16, n. 1, p. 133-144, 2019.

BIANCHI, Graziela; PERSEGONA, Naiara Namma Perdigão. O lugar do jornalismo no continumm entre discussões de gênero e violência contra a mulher. In: 16을 Encontro Nacional de Pesquisadores em Jornalismo, 2018, São Paulo. Anais do 16 Encontro Nacional de Pesquisadores em Jornalismo SBPJor - Associação Brasileira de Pesquisadores em Jornalismo. São Paulo: Universidade Anhembi Morumbi, 2018, p. 118.

ENGELS, Friedrich. A origem da família, da propriedade privada e do Estado. Rio de Janeiro: Civilização brasileira, 1984.

ENTMAN, Robert. Framing: Toward Clarification of a Fractured Paradigm. Journal of Communication, v. 43, n. 4, p. 51-58, 1993. Disponível em:https://doi.org/10.1111/j.14602466.1993.tb01304.x. Acesso: 22 nov. 2019.

FEDERICI, Silvia. O ponto zero da revolução. São Paulo: Editora Elefante, 2019. 


\title{
REVISTA PAUTA GERAL
}

\section{ESTUDOS EM JORNALISMO}

\author{
10.5212/RevistaPautaGeral.v.6.i2.0002
}

GÓES, José Cristian. Jornalismo e Sensacionalismo: Enquadramento, criminalização da pobreza e implicações éticas no Jornal Cinform. Dissertação (Pós-Graduação em Comunicação) - Universidade Federal de Sergipe, UFS, Aracaju, 2014.

GRUPPI, L. O conceito de hegemonia em Gramsci. Rio de Janeiro: Graal, 1978.

HALL, Stuart. Encoding/Decoding. In: Culture, Media, Language: Working papers in cultural studies, 1972-1979. London: Hutchinson, 1980.

LAGE, Leandro; CAL, Danila; SILVA, Bárbara. Vulnerabilidade e resistência: enquadramentos da condição da mulher mãe na cobertura jornalística sobre o parto. In: 16을 Encontro Nacional de Pesquisadores em Jornalismo, 2018, São Paulo. Anais do 16은 Encontro Nacional de Pesquisadores em Jornalismo SBPJor - Associação Brasileira de Pesquisadores em Jornalismo. São Paulo: Universidade Anhembi Morumbi, 2018, p. 1-16.

MARCONDES FILHO, Ciro. Capital da Notícia: Jornalismo como produção social da segunda natureza. 2ª edição. São Paulo: Editora Ática, 1989.

MARQUES, Ângela Cristina Salgueiro; BIONDI, Angie. Um programa de face feminina: uma leitura dos enquadramentos biopolíticos de mulheres empobrecidas em fotografias jornalísticas do Bolsa Família. In: 16ํㅡㄹ Encontro Nacional de Pesquisadores em Jornalismo, 2018, São Paulo. Anais do 16 Encontro Nacional de Pesquisadores em Jornalismo SBPJor - Associação Brasileira de Pesquisadores em Jornalismo. São Paulo: Universidade Anhembi Morumbi, 2018, p. 1-15.

MORAES, Dênis de. Comunicação, Hegemonia e Contra-Hegemonia: a contribuição teórica de Gramsci. Revista Debates, Porto Alegre, v.4, n.1, p. 54-77, 2010.

MORETZSOHN, Sylvia. Jornalismo em tempo real: $O$ fetiche da velocidade. Rio de Janeiro: Revan, 2007.

PORTO, Mauro. Elementos da Mídia e Política. In: XXVI Encontro Anual da Associação Nacional de Pós-Graduação e Pesquisa em Ciências Sociais, 2002, Caxambu. Anais do XXVI Encontro Anual da Associação Nacional de Pós-Graduação e Pesquisa em Ciências Sociais - ANPOCS. Caxambu, 2002, p. 1-26.

SAAD, Maria Amélia Pedro. A Trama das Mulheres Invisíveis: Análise da Abordagem de Feminicídio Íntimo no Jornalismo Popular. Dissertação (Mestrado em Ciências) Instituto Nacional de Saúde da Mulher, da Criança e do Adolescente Fernandes Figueira, FIOCRUZ, Rio de Janeiro, 2018.

SAFFIOTI, Heleieth. Gênero, patriarcado, violência. São Paulo: Expressão Popular, 2015

SANTOS, Ana Claudia Lemos. Representações sociais do homicídio de mulheres no Jornal Zero Hora. Dissertação (Pós-Graduação em Ciências Sociais) - Pontifícia Universidade Católica do Rio Grande do Sul, PUC-RS, Porto Alegre, 2018. 


\section{REVISTA PAUTA GERAL}

\section{ESTUDOS EM JORNALISMO}

10.5212/RevistaPautaGeral.v.6.i2.0002

QUIRINO, Kelly Tatiane Martins; MOURA, Dione Oliveira. Enquadramento jornalístico do genocídio de jovens negros: estudo de caso da Chacina de Costa Barros na Folha de S. Paulo. In: 16 Encontro Nacional de Pesquisadores em Jornalismo, 2018, São Paulo. Anais do 16을 Encontro Nacional de Pesquisadores em Jornalismo SBPJor Associação Brasileira de Pesquisadores em Jornalismo. São Paulo: Universidade Anhembi Morumbi, 2018, p. 1-20.

Recebido em: 15/10/2019

Aprovado em: 11/11/2019 